"Przegląd Prawa Konstytucyjnego"

Nr 1 (13)/2013 ------

\title{
Recenzja
}

\section{Środki ochrony praw stusznie nabytych w'świetle Konstytucji RP i prawa Unii Europejskiej, red. Halina Zięba-Załucka i Paweł Chmielnicki, LexisNexis, Warszawa 2012, ss. 332}

Redaktorzy naukowi Halina Zięba-Załucka i Paweł Chmielnicki zadali sobie trud i podjęli się analizy zasady ochrony praw słusznie nabytych. Owe prawa są jednymi z najważniejszych praw obywateli, jednakże nie zostały jednoznacznie sformułowanie w Konstytucji. Dlatego też zaproszeni do publikacji Autorzy poszczególnych rozdziałów analizują tytułową materię z perspektywy różnych dziedzin prawa. Publikacja została podzielona na trzy bloki tematyczne. Począwszy od: Kategorii praw stusznie nabytych $w$ prawie polskim i prawie Unii Europejskiej. Skuteczności tradycyjnych środków ochrony praw stusznie nabytych $w$ dobie globalizacji $i$ ekspansji cyberprzestrzeni - stanowi siedem testów, po Funkcje administracji publicznej a tworzenie warunków do wykonywania praw słusznie nabytych. Ważne jest, że do tej pory na rynku wydawniczym nie było pozycji, która w całości dotyczyła praw słusznie nabytych. Tom otwiera artykuł Haliny Zięby-Załuckiej dotyczący Zasady ochrony praw nabytych jako element zasady demokratycznego państwa prawnego. Autorka pochyla się w nim nad m.in. ochroną praw nabytych w orzecznictwie Trybunału Konstytucyjnego oraz zasad wyprowadzonych z demokratycznego państwa prawnego. Jednym z najważniejszych wniosków, jakie powinniśmy wyciągnąć po zapoznaniu się z artykułem, to fakt, że „problem prawnego charakteru praw nabytych jako zasady konstytucyjnej nie był i nie jest zrozumiały jednoznacznie" (s. 29), na co wskazuje Autorka.

Kolejnym przedstawionym czytelnikowi materiałem jest tekst Jerzego Jaskierni, który skupia swą uwagę na ochronie praw nabytych jako przesłanki procesu decyzyjnego w parlamentarnym postępowaniu ustawodaw- 
czym. Swoje badania nad wybranym zagadnieniem Autor poparł bardzo bogatym orzecznictwem Trybunału Konstytucyjnego. Wnioski wyciągnięte z praktycznego punktu widzenia każą nam stwierdzić, że ciężko jest przede wszystkim w postępowaniu ustawodawczym dotrzymać standardów ochrony praw nabytych i - jak podkreśla J. Jaskiernia - jest to cały czas wyzwanie dla ustrojodawcy.

Mechanizm nabywania praw podmiotowych to temat zainteresowania kolejnego Autora - Iwony Niźnik-Dobosz. Autorka prowadzi rozważania dotyczące przedmiotu praw słusznie nabytych, a co się tym łączy pojęciu praw podmiotowych, wyróżnieniu ich typów (prawa-uprawnienia i prawa-kompetencje), ale również praw podmiotowych jako punktu wyjścia porządku prawnego.

Kolejnym ciekawym zagadnieniem podjętym w tomie jest miejsce zasady ochrony praw nabytych w kanonie zasad i wartości konstytucyjnych. Maciej Borski swoje rozważania na ten temat rozpoczął od pojęcia i genezy zasady przyzwoitej legislacji. Autor wyciąga podstawowy wniosek - że prawo stworzone powinno być godne zaufania. W dalszej części tekstu swobodnie przechodzi do zagadnienia podstaw zasady praw słusznie nabytych, gdzie wszystkie rozważania są poparte przytaczanym bogatym orzecznictwem Trybunału Konstytucyjnego. W podsumowaniu Autor słusznie zauważa, że polska kultura prawna się zmienia na rzecz reguł interpretacyjnych przy zerwaniu z zasadą bezpośredniego działania regulacji prawnych.

Analiza „nieiflacyjnego wzrostu” w prawie europejskim Jerzego Menkesa jest ostatnim opracowaniem w części pierwszej publikacji. Autor, zapoznając odbiorcę z tematem głównym, przedstawia takie terminy jak „inflacja”, „waloryzacja” czy „nominalizm”, norma „nieiflacyjnego wzrostu” została przedstawiona w sposób dogmatycznoprawny.

Część drugą publikacji otwiera tekst Izabeli Karaszewskiej, która skupia uwagę na ochronie praw nabytych w orzecznictwie Trybunału Konstytucyjnego. Podejmuje rozważania na temat celu ochrony praw i możliwości wprowadzenie zmian polegających na redukcji bądź ograniczeniu praw. Całość swoich rozważań Autorka podpiera tylko orzecznictwem Trybunału Konstytucyjnego bez przytaczania literatury przedmiotu poza jedną pozycją.

Opracowania ciekawego zagadnienia podjął się Marian Liwo - mianowicie Ochrony pracy w Konstytucji RP z 2 kwietnia 2007 r. i prawie między- 
narodowym oraz Unii Europejskiej. Autor swoje rozważania rozpoczyna od rozważań tytułowych poprzez rozwinięcie ich w zakresie przepisów bezpieczeństwa i higieny pracy po uwarunkowania zapewnienia powyższych.

Materiał przygotowany przez Helenę Szewczyk traktuje o kategoriach praw słusznie nabytych w prawie urzędniczym. To kolejny aspekt, w którym kwestia praw nabytych jest rozważana w niniejszym tomie. Aleksander Słysz podejmuje rozważania w kontekście prawa podatkowego. Autor stawia następujące pytania i toczy nad nim swoje rozważania - „Czy zasada praw słusznie nabytych jest tzw. zasadą podatkową?” (s. 194). Niestety analiza zaczyna się dopiero w części siódmej artykułu, część tę poprzedza dość długi wstęp do kluczowego zagadnienia. Hubert Kaczmarczyk natomiast podjął temat problemu emerytur mundurowych. Autor po krótkim wprowadzenie przechodzi do meritum zagadnienia, w sposób jasny i kompleksowy wyjaśnia, czym jest ochrona praw nabytych, a czym ekspektatywa tych praw. Kolejny tekst Grażyny Zięby-Białowąs zwraca naszą uwagę na temat Ochrony praw nabytych a sędziowskiego i prokuratorskiego stanu spoczynku. Jest to materiał opracowany przez praktyka (Autorka jest prokuratorem Prokuratury Apelacyjnej w Rzeszowie), co daje jeszcze szerszy obraz analizowanego zagadnienia. Analizę problemu kończy natomiast, wyciągając wnioski, które powinny zainteresować wszystkich czytelników, mianowicie że prawa raz nabyte powinny być stabilne. Osoby, którym przyznano prawo raz, nie powinny myśleć, że może zostać ono odebrane lub - jak wskazuje Autorka - naruszone. Wspólny artykuł Pawła Bały i Mariusza Załuckiego dotyczy pozbawienia orderów i odznaczeń. Autorzy po przedstawieniu podstaw prawnych i trybu nadawania odznaczeń i orderów po główne zagadnienie, Autorzy we wnioskach końcowych zaznaczają, że według nich przyjęta w ustawie konstrukcja pozbawiania orderów i odznaczeń jest niewłaściwa.

Część trzecią poświęconą funkcją administracji publicznej otwiera tekst Mateusza Pszczyńskiego pod tytułem: Ochrona praw nabytych i ochrona interesów w toku a gminne uchwały podatkowe. W podsumowaniu Autor wskazuje, że przyznawanie zwolnień podatkowych, a następnie ich odebranie jest sytuacją niedopuszczalną. Części trzeciej opracowania znalazły się ponadto teksty Anny Makowiec i Piotra Ruczkowskiego. Pierwszy, traktujący o Zasadzie trwałości decyzji administracyjnych według zasady ochrony praw nabytych, a drugi dotyczący Zasady trwałości aktu administracyjnego oraz aktu 
normatywnego administracji w czasie jako środek ochrony praw słusznie nabytych. Obydwa teksty merytorycznie odpowiadają części trzeciej tomu.

Materiał dotyczacy wywłaszczenia nieruchomości w kontekście rzeczy publicznej $w$ znaczeniu infrastrukturalnym a zasada praw stusznie nabytych to tekst opracowany przez Leszka Bieleckiego. Sam Autor w podsumowaniu tekstu pisze, że ów materiał dotyczy wyłącznie nieruchomości, która była we władaniu innego podmiotu niż administracja publiczna. Tom zamyka artykuł Wojciecha Goneta dotyczący Ochrony umownego prawa pierwokupu. Tekst jest jednym z krótszych w tomie. Składają się na niego dwie części: pierwsza dotycząca ochrony uprawnionego z tytułu umownego prawa pierwokupu i druga dotycząca zmian regulacji dotyczącej prawa pierwokupu.

Reasumując: lektura nowej pozycji wydawniczej była ciekawym doświadczenie. Temat praw słusznie nabytych został przedstawiony w różnych aspektach prawnych, co sprawiło, że całość nie była jednorodna i każdy z potencjalnych odbiorców powinien odnaleźć interesujące go zagadnienie. Dodatkowo na wysoką ocenę zasługuje strona edytorska publikacji, tekst jest przejrzysty, wydawca zadbał, aby kolejne części tekstu były wyraźnie wyróżnione.

Judyta Węgłowska (Akademia Humanistyczo-Ekonomiczna w Łodzi) 